\title{
THE ROLE OF LAW AND SHARIAH GOVERNANCE IN ISLAMIC FINANCE TOWARDS SOCIAL JUSTICE IN DIVERSITY
}

\author{
Ruzian Markom \\ Faculty of Law, Universiti Kebangsaan Malaysia \\ ruzian@ukm.edu.my
}

\begin{abstract}
Comprehensive law and Shariah governance framework are important in ensuring the sustainability of Islamic financial goal. Both elements contributed in the process of social justice in diversity between the industry and the society. This article is aimed to discuss on the role of law and Shariah governance in Islamic finance towards social justice in diversity. It defined the meaning of laws, Shariah governance and social justice in diversity in the context of Islamic finance. Then, it analysed the challenges of Islamic finance in promoting social justice in diversity. Finally, in resolving the challenges, it is recommended to adopt the six key areas laid down in the World Global Report 2016.
\end{abstract}

Keywords: Law; Shariah Governance; Islamic Finance; Social Justice; Diversity.

\section{Introduction}

Comprehensive law and Shariah governance framework is essential to ensure the sustainability of Islamic finance goals. Both elements are essential towards the process of social justice in diversity. Islamic finance plays important role in promoting the Sustainable Development Goals (SDGs) for the global development agenda of 2015-30. ${ }^{1}$ The transformative and sustainable nature of the new development agenda as well as the principles of Islamic finance which support socially inclusive and development-promoting activities has the potential to contribute to the achievement of the SDGs. Mobilization of Islamic financial institutions, capital markets, and the social sector in promoting strong growth, enhanced financial inclusion and intermediation; reducing risks and vulnerability of the poor contributing to financial stability and development will be pivotal in achieving the SDGs in countries with a serious commitment to Islamic finance. This paper is aimed to discuss on the role of law and Shariah governance in Islamic finance towards social justice in diversity. It will define the meaning of laws, Shariah governance and social justice in diversity in the context of Islamic finance. Then, it will analyse the challenges of Islamic financial industry in promoting social justice in diversity. Finally, it will recommend steps to overcome the challenges.

\footnotetext{
${ }^{1}$ Thomson Reuters. ICD - Thomson Reuters Islamic Finance Development Report 2016.(Jeddah: ICD, 2016$), 5$.
} 


\section{Method}

This study adopted an empirical juridical method. In empirical legal research, the social sciences are used to analyze and provide answers to make effective the entire legal institutional structure. ${ }^{2}$ This study examines the interrelationships between law and social justice in diversity in the area of Islamic finance. Descriptive analytical specifications is applied in identifying the problems in Islamic finance as well as the procedures that apply in the industry and society , including about the relationships of activities, attitudes, views, and ongoing processes and influences from a phenomenon. As a result, the analytical descriptive method describes the state of the object under study and a number of factors that influence the data obtained are collected, compiled, explained, and then analyzed.

\section{Results and Discussion}

\subsection{Law in the Context of Islamic Finance}

Law is defined as set of rules and conduct with binding legal effect, prescribed, recognized, and enforced by controlling authority. ${ }^{3}$ In the context of Islamic finance, law includes both conventional and Shariah laws. Conventional laws varies according to the jurisdiction of the countries. Commonwealth countries like Malaysia adopted common law system while Indonesia is a civil law system. The common law system is the system of jurisprudence that is based on the doctrine of judicial precedent, the principle under which the lower courts must follow the decisions of the higher courts, rather than on statutory laws. ${ }^{4}$ The sources of laws consists both written laws and laws common to the state. Among the types of laws are subsidiary laws like the law of contract and regulatory laws namely the laws that regulates the Islamic financial industries like Islamic Financial Services Act 2013. On the other hand, civil law system is a legal system originating in Europe, intellectualized within the framework of late Roman law, and whose most prevalent feature is that its core principles are codified into a referable system which serves as the primary source of law. ${ }^{5}$ In Indonesia for instance, Act of The Republic Indonesia Number 21 of 2008 concerning Sharia (Islamic) Banking and Number 40 concerning insurance and Shariah Insurance. Finally, Shariah is a divine law. It is ordained from the God to human beings to follow the rules and conduct to the

\footnotetext{
${ }^{2}$ Mc Conville,M \& Wing Hong Chui. Research Methods for Law. (Edinburgh: Edinburgh University Press, 2017),5.

${ }^{3}$ Glanville Williams. $15^{\text {th }}$ Edition. Learning the Law. (London: Sweet\& Maxwell, 2013),5.

${ }^{4}$ Glanville Williams. 15th Edition. Learning the Law. (London: Sweet\& Maxwell, 2013),10.

${ }^{5}$ H.Amran Suadi et.al. Politik Hukum Persepktif Hukum Perdata dan Pidana islam Serta Ekonomi Syariah (Jakarta

: Kencana, 2016), 7.
} 
right path. The sources of Shariah laws are divided into primary sources like Al Quran, Al Sunnah, Al Ijmak and Al Qiyas as well as secondary sources like AlIstihsan, Masalih Mursalah and al A'dah Muhkamah. ${ }^{6}$ In the context of Islamic finance, the harmonization of conventional laws and shariah laws are required to govern the operations and products of Islamic finance industry.

\subsection{Understanding Shariah Governance}

Shariah governance is about responsibility of the management to develop and adopt a holistic culture of Shariah compliance within the organisation. ${ }^{7}$ A holistic culture of Shariah compliance refers to the way in which the Islamic Financial Institutions complies with Shariah principles in its overall Islamic financial business operations. ${ }^{8}$ The Malaysian government have introduced the Shariah Governance Framework(SGF) in 2012. The SGF is the main reference on the functions of the Shariah Committee, their scope of responsibilities in carrying out the Shariah compliance functions of Shariah Review, Audit, Risk Management and Research and their liabilities for advice provided. ${ }^{9}$ The SGF upholds the supremacy of the Shariah Advisory Council(SAC) where in the event of any conflict of rulings made by Shariah Committee and the SAC, rulings made by SAC shall prevail. ${ }^{10}$

Accordingly, corporate governance is the system of rules, practices and processes by which a company is directed and controlled. Corporate governance essentially involves balancing the interests of a company's many stakeholders, such as shareholders, management, customers, suppliers, financiers, government and the community. ${ }^{11}$

The above explanations on governance shows that both Shariah and corporate governance shares the same objectives of transparent governance. Nevertheless, it distinct in the context of

\footnotetext{
${ }^{6}$ Abdul Halim El-Muhammady. Syariah Perkembangan dan Tuntutan Pelaksanaan.(Bandar Baru Bangi: Wadah Niaga, 2005), 10.

${ }^{7}$ Abdurrahman Raden Aji Haqqi. "Shariah Governance in Islamic Financial Institution : An Appraisal”.11 UsChina.L.Rev.pp.113.

${ }^{8}$ Mohd Izzat Amsyar Mohd Arif, Ruzian Markom, Mohd Arif Ismail. "Wasatiyyah values appreciation in the Syariah governance as consumer understanding education mechanisme towards Islamic banking system". International Journal of Educational Best Practices. Vol 1. No. 1. April 2017, pp. 110.

${ }^{9}$ Bank Negara Malaysia. (2016). Concept Paper - Corporate Governance. http://www.bnm.gov.my/guidelines/01_banking/04_prudential_stds/Concept\%20Paper_C orporateGovernance.pdf [25 Oktober 2018]

${ }^{10}$ Bank Negara Malaysia. (2012). Syariah Advisory Council of the Bank.

http://www.bnm.gov.my/index.php?ch=7\&pg=715\&ac=802 [25 Oktober 2018]

${ }^{11}$ Chapra, Ahmed Habib. Corporate Governance in Islamic Financial Institutions. Occasional Paper No. 6.( Jeddah: Islamic Research and Training Institute/Islamic Development Bank, 2002), 2.
} 
implementing Shariah rules and regulations in the operations and product of Islamic financial institutions and Shariah compliance of the Institutions.

\subsection{Understanding Social Justice in Diversity in the Context of Islamic Finance}

Black's Law dictionary defined social justice as fair and proper administration of the laws that conform to the natural law that covers all people regardless of gender, origin, possessions or religion. ${ }^{12}$ In this context, social justice is based on the concepts of human rights and equality, and can be defined as "the way in which human rights are manifested in the everyday lives of people at every level of society". ${ }^{13}$ Indeed, economic justice is a component of social justice. It is a social institution when justly organized, will provide access to what is good for the person, both individually and in the community. The Global Report on Islamic Finance 2016 entitled Islamic finance : A catalyst of Shared Prosperity has extended the definition of social justice to shared prosperity concept. The concept shared prosperity is implemented through the principles of inclusive participation and risk sharing. ${ }^{14}$

In defining the concept of diversity, it is inevitable to include the concept of inclusion. Thus, the concept of diversity and inclusion cannot be separated. The concept of diversity is a process and goal on empowering people. ${ }^{15}$ Fundamentally, diversity means respect for and appreciation of differences in age, gender, ethnicity, religion, disability, sexual orientation, education, and national origin that are implemented by laws and policies. ${ }^{16}$ Applying diversity in conjunction with inclusion allows individuals and groups of people to be recognised as being unique whilst recognizing individual differences. Diversity allows for the exploration of these differences in a safe, positive, and nurturing environment. Understanding each other and surpassing simple tolerance allows us to not only embrace but also celebrate the rich dimensions of diversity contained within each individual and place positive value on diversity in the community and in the workforce.

Inclusion is an organizational effort and practices in which different groups or individuals having different backgrounds such as national origin, age, race and ethnicity, religion/belief,

\footnotetext{
${ }^{12}$ Bryan A Garner (Editor in Chief). Black's Law Dictionary. 10 ${ }^{\text {th }}$ Edition. (Eagan, United States: Thompson West, Aspatore Books, 2014), 110.

${ }^{13}$ Rania Kamla, Hussain G. Rammal.(2013). "Social Reporting by Islamic Banks: does social justice matter?”. Accounting, Auditing \& Accountability Journal. Vol.26. Issue: 6, pp. 920. [25 Oktober 2018]

${ }^{14}$ World Bank and Islamic Development Bank Group. 2016. Global Report on Islamic Finance: Islamic Finance: A Catalyst for Shared Prosperity. Washington, DC: World Bank.

${ }^{15}$ Stuart Hannabus.(2105). "Encylopedia of Diversity and Social Justice".Refernce Reviews. Vol.29. Issue 6, pp.2022. https//doi/10/1108/RR-06-2015-0165. [25 Oktober 2018]

${ }^{16}$ Camille Kapoor.(2011). "Defining Diversity: the evolution of diversity". Worldwide Hospitality and Tourism Themes. Vol.3. Issue: 4, pp.284-293. https://doi.org/10.1108/17554211111162408. [25Oktober 2018].
} 
gender, marital status and socioeconomic status. Inclusion is a sense of belonging: feeling respected, valued for who you are as an individual or group; feeling a level of supportive energy and commitment from others so that you can do your best at work. Inclusion is a shift in an organisation's mindset and culture. The process of inclusion engages each individual and makes people feel valued which is essential to the success of the organization. In simple words . diversity is the mix while inclusion is making the mix work. ${ }^{17}$

In Islamic finance diversity of opinion is a mercy. Ikhtilaf, connotes disagreement, difference of opinion and diversity of views among the jurist of Islamic law. According to a saying of the Prophet Muhammad, diversity among the Muslim people is a blessing (ikhtilafu ummati rahma). The Islamic tradition takes pride in sciences developed for studying the differences in the recitation and interpretation of the Qur'an and the differences in the transmissions of the Hadith, reports about Prophet Muhammad's statements, and the Sunnah, his practices. Since the beginning of the development of fiqh, ikhtilaf among the jurists not only existed, but was also respected.

\subsection{Challenges of Islamic Finance Towards Social Justice in Diversity}

In achieving the social justice in diversity, Islamic finance is facing the following challenges:

\subsubsection{Lack of consistency in product structure and investment practices}

Islamic financial institutions finding it challenging to cope with the evolving global environment and making appropriate rules and regulations to cope with these changes while still remaining competitive with their conventional counterparts. Additionally, the industry lacks consistency in product structures and investment practices that adversely affects its credibility, reputation, perception and regulation capabilities.

Islamic banks are essentially governed by their Shariah boards - the religious scholars that deem a product Shariah-compliant. But the challenge is that there is no central authority

${ }^{17}$ Camille Kapoor.(2011). "Defining Diversity: the evolution of diversity".Worldwide Hospitality and Tourism Themes. Vol.3. Issue: 4, pp.284-293. https://doi.org/10.1108/17554211111162408. [25Oktober 2018]. 
promulgating Shariah law, and the understanding of what is hence permissible and what is not varies among Islamic scholars and jurisdictions.

\subsubsection{Lack of Global Shariah Harmonisation}

The rapid growth of Islamic banking over the years has resulted in the introduction of complex banking products and structures, which now require Shariah harmonisation at a global level. At present, that harmonisation is lacking. For example, the Islamic contract of Tawwaruq or Commodity Murabaha is only allowed by certain scholars. Similarly Bai-al-dain, or sale of debt, although disallowed by the majority of Muslim scholars, is allowed by some scholars in Malaysia. Recently, a prominent Shariah scholar concluded that approximately $85 \%$ of Sukuks in the market fall short of basic Shariah principles.

While conventional banks have harmonised and approved regulatory standards that banks around the world follow, making it easier for them to expand and conduct operations in different countries, there are no approved standards per se for Islamic banks; they follow the conventional banking regulations.

But because Islamic banking differs from conventional banking, it is difficult for Islamic banks to completely follow these global conventional standards. For instance, the capital structure in Islamic banks is different from that of conventional banks.

It is imperative for the Islamic banking industry to focus on the development of products that foster market integration and attract investors and entrepreneurs to the risk-return characteristics of the product rather than concentrating only on its Shariah compliance. Islamic banks need to invest in the research and the development of new products that are acceptable by a "Global Shariah Board." 


\subsubsection{Diversified Shariah Opinion on product and services}

At the moment, there is a dilemma as Shariah opinion is diversified, leading to situations where one school of thought may approve a product or service as being Shariah-compliant only for it to be rejected by another school of thought. A big step towards achieving harmony would be to set up a central board at a global level with representation from all different schools of thought.

For harmonising standards and structures, the industry does encourage ijtihad in the global community through international conferences and convocations. Organisations such as the Islamic Financial Services Board (IFSB) and the Accounting and Auditing Organisations for Islamic Financial Institutions (AAOIFI) have been formed to recommend principles and industry best practices at global levels.

However, these organisations unfortunately have no binding powers to implement their standards on the industry and they merely develop recommendations. If Islamic banking is to achieve its potential, it needs to be supported by governments and regulators. Most importantly, all aspects of Shariah compliance need to be properly defined; ultimately the harmonisation of Shariah compliance is a critically important component to ensuring the stability, which is intrinsic to the Islamic finance model.

\subsection{Resolving the Challenges of Social Justice in Diversity in Islamic Finance}

In resolving the challenges of social justice in diversity in Islamic finance, The World Global Report 2016 have laid down six key areas for improvement and adopt best practices:

\subsubsection{Key Area 1}

Creating an enabling regulatory environment by supporting consistent regulations, ensuring consistent implementation of the Basel III and Islamic Financial Services Board (IFSB) 
frameworks, ensuring that systemic risks in dual banking systems (conventional and Islamic) are addressed, and implementing cross-border supervision;

\subsubsection{Key Area 2}

Introducing innovative risk-sharing products and services, rather than replicating conventional risk-transfer products;

\subsubsection{Key Area 3}

Harmonizing shariahh governance through efforts to unify cross-country shariahh rulings about Islamic finance, which would help accelerate the growth of the industry. Improvement in the shariahh governance framework is needed to enhance shariahh compliance, credibility, and integrity. A strong shariahh governance framework helps increase consumer confidence and provides greater flexibility for Islamic financial institutions to be innovative within the boundaries of shariahh. The shariahh board contributes to public awareness about the philosophical basis and concepts of Islamic banking and finance. Shariahh governance adds value to the existing corporate governance framework in Islamic financial institutions. ;

\subsubsection{Key Area 4}

Enhancing the scale of and access to Islamic finance to include low-income earners;

\subsubsection{Key Area 5}

Improving liquidity and ensuring stability; and

\subsubsection{Key Area 6}

Bolstering human capital and literacy in Islamic finance.

The first two areas are prerequisites, while the last two are the channels to achieve sustainable development with equitable distribution of both opportunities and wealth, which are the main objectives of the concept of economic development in Islam. The proposed framework, which is constructed by interpreting central tenets of Islamic principles, could be used in creating 
a universal strategy and policy that align with the principles of Islamic finance to achieve the goal of sustainable development and to increase the welfare of all members of the society.

The analysis showed that Key Area 1 is crucial because having a sound institutional framework and appropriate public policies are the foundation upon which the other areas must rest and can function optimally. Institutions play a critical role in this framework, as they implement the rules prescribed by the tenets of Islam. The institutions also must adhere to the core objectives of Islam (commonly known as maqasid al-shariah or Objectives of Islamic Law) that lay the foundation to formulate the policies promoting economic and social justice, preservation of human rights dignity, health, and the intergenerational wealth of the society.

Accordingly, Key Area 2 focuses on developing a governance mechanism and accompanying compliance system based on the objectives and institutions briefly outlined in the first step. The ethically based governance, leadership, and compliance system helps increase the transparency and accountability in the public, private, and social sector institutions of the overall economic system and hence strengthens trust in the system. Trustworthy and capable leadership can ensure protection of rights of the vulnerable or those who could be vulnerable (as in future generations). Increased trust and better governance in turn strengthen the institutional framework that enables better implementation of better public policies.

The desired institutional and governance structure must be able to do the following:

a. Design policies to foster inclusive growth and development by promoting entrepreneurship, risk-sharing financial transactions, and equity participation, and by discouraging financial leverage and speculation.

b. Encourage all members of society to contribute to the creation of economic, social, human, and moral capital.

c. Enhance the equitable distribution of wealth by promoting sharing of both risk and rewards 
d. Alleviate poverty by redistributing wealth, with special focus on the poorest.

e. Achieve economic and social justice by the correct use of material growth and development that enhances the overall well-being of the society.

Key Area 3 and 4 are the distribution channel; it works at both the individual and organizational level. One of the main features is the advocacy of risk sharing and promotion of entrepreneurship. This is one of the most important aspects of Islamic finance, which differentiates it from the conventional approach of overreliance on debt-dominated risk-shifting or risk-transfer mechanisms. Sharing the risks of economic and financial transactions also ensures the stability of the financial system . In addition, risk sharing with equitable sharing mechanisms encourages entrepreneurship and innovation, since counterparties receive their fair share in the investment. This in turn will increase the allocation of resources to the real sector, rather than channeling excessive financial flows to the financial sector (overfinancialization).

Key Area 5 and 6 aims to ensure that the fruits of the higher growth are distributed to every segment of the society inclusively, either through participation in the economic growth or through Islam's instruments of redistribution.

\section{Conclusion}

In conclusion, comprehensive law and shariah governance framework plays important role towards social justice in diversity. Sound and workable framework will assist in achieving sustainable development with equitable distribution of both opportunities and wealth, which are the main objectives of the concept of economic development in Islam. The proposed framework, which is constructed by interpreting central tenets of Islamic principles, could be used in creating a universal strategy and policy that align with the principles of Islamic finance to achieve the goal of sustainable development and to increase the welfare of all members of the society. 


\section{Acknowledgement}

Acknowledgement to the Secretariat of First International Conference on the Challenges of Law, Economic and Governance toward Social Justice in Diversity, Universiti Diponegoro, Semarang, Indonesia and the Faculty of Law, Universiti Kebangsaan Malaysia for inviting me as Plenary Speaker at the Conference.

\section{References}

Abdurrahman Raden Aji Haqqi. (2014). "Shariah Governance in Islamic Financial Institution : An Appraisal”.11 Us-China.L.Rev.pp.112-133.

Abdurrahman Raden Aji Haqqi. (2017). "Regulatory Regimes of Islamic Banking in ASEAN Economic Community (AEC): A Uniting Force in the Region”. Advances in Social Sciences Research Journal. Vol.4. No. 13 pp.24-39.

Abdul Halim El-Muhammady. (2005). Syariah Perkembangan dan Tuntutan Pelaksanaan.Bandar Baru Bangi: Wadah Niaga.

Bank Negara Malaysia. (2010). Resolusi Syariah Dalam Kewangan Islam Edisi Kedua. http://www.bnm.gov.my/files/press_release/2010/shariah_resolutions_2nd_edition.pdf [25 Oktober 2018]

Bank Negara Malaysia. (2012). Syariah Advisory Council of the Bank. http://www.bnm.gov.my/index.php?ch=7\&pg=715\&ac=802 [25 Oktober 2018]

Bank Negara Malaysia. (2016). Concept Paper - Corporate Governance. http://www.bnm.gov.my/guidelines/01_banking/04_prudential_stds/Concept\%20Paper_C orporateGovernance.pdf [25 Oktober 2018]

Bank Negara Malaysia. Laporan Kestabilan Kewangan dan Sistem Pembayaran 2009.

Bryan A Garner (Editor in Chief).(2014). Black's Law Dictionary. 10 ${ }^{\text {th }}$ Edition. Eagan , United States: Thompson West, Aspatore Books.

Chapra, Ahmed Habib. (2002). Corporate Governance in Islamic Financial Institutions. Occasional Paper No. 6. Jeddah: Islamic Research and Training Institute/Islamic Development Bank.

Camille Kapoor.(2011). "Defining Diversity: the evolution of diversity".Worldwide Hospitality and Tourism Themes. Vol.3. Issue: 4, pp.284-293. https://doi.org/10.1108/17554211111162408. [25Oktober 2018].

DBS Asian Insights Sector Briefing 39 Islamic Banking The Unconventional Aspect. DBS Group Research. 
Glanville Williams. (2013) 15th Edition. Learning the Law. London: Sweet\& Maxwell.

H.Amran Suadi et.al.(2016) Politik Hukum Persepktif Hukum Perdata dan Pidana islam Serta Ekonomi Syariah . Jakarta : Kencana.

Mc Conville,M \& Wing Hong Chui. (2017) Research Methods for Law. Edinburgh: Edinburgh University Press.

Mohd Izzat Amsyar Mohd Arif, Ruzian Markom, Mohd Arif Ismail.(2013). "Wasatiyyah values appreciation in the Syariah governance as consumer understanding education mechanisme towards Islamic banking system". International Journal of Educational Best Practices. Vol 1. No. 1. April 2017, pp. 109-120.

Mohd Izzat Amsyar Mohd Ariff, Ruzian Markom.(2017). "Peranan dan Kedudukan Majlis Penasihat Shariah untuk Memperkasakan Sistem Kewangan Islam di Malaysia”.Jurnal Pengurusan. Vol 38.

Rania Kamla, Hussain G. Rammal.(2013). "Social Reporting by Islamic Banks: does social justice matter?”. Accounting , Auditing \& Accountability Journal. Vol.26. Issue: 6, pp. 911-945. [25 Oktober 2018]

Stuart Hannabus.(2105). “Encylopedia of Diversity and Social Justice”.Refernce Reviews. Vol.29. Issue 6, pp.20-22. https//doi/10/1108/RR-06-2015-0165. [25 Oktober 2018]

Sayyid Qutb. Translated by John B. Hardie. TranslationRevised and Intrduction by Hamid Algar. (2000).Social Justice in Islam. Petaling Jaya:Islamic Book Trust.

Thomson Reuters. ICD-Thomson Reuters Islamic Finance Development Bank Report 2016. Jeddah: ICD. https://www.icd-ps.org.[25 Oktober 2018]

World Bank and Islamic Development Bank Group. 2016. Global Report on Islamic Finance: Islamic Finance: A Catalyst for Shared Prosperity. Washington, DC: World Bank. doi:10.1596/978-1-4648-0926-2. License: Creative Commons Attribution CC BY 3.0 IGO. Islamic finance: The unconventional but nascent financial system. http://www.theborneopost.com/2017/03/05/islamic-finance-the-unconventional-but-/ Oktober 2018] 